\title{
無補強角形鋼管柱・梁接合部のモーメント一回転角関係の一般化 GENERAL MOMENT-ROTATION CHARACTERISTICS OF BEAM-TO-RHS-COLUMN CONNECTIONS WITHOUT DIAPHRAMS
}

\author{
秋山 宏*, 吳 相勲**, 大竹章夫***, 福田浩司****, 山田 \\ Hiroshi AKIYAMA, Sang-Hoon OH, Fumio OTAKE, \\ Koji FUKUDA and Satoshi YAMADA
}

\begin{abstract}
A key parameter to measure the seismic resistance of steel frames is the ability to absorb energy by undergoing elastic-plastic deformations. In the rigid moment frames, the energy is absorbed by columns, beams and joint panels of beam-to-column connections. On the other hand, in the case of semi-rigid moment frame, beam-to-column connections can absorb energy in addition to these members.

In this paper, the results of experiments of non-diaphram connection with use of RHS column and $\mathrm{H}$-setional beam is reported, and empirical formulas to estimate yield moment and stiffness are proposed.
\end{abstract}
Keywords : semi-rigid connection, non-diaphram, moment frame, weld built up, roll forming
半剛接接合部, 無補強, モーメント骨組, 溶接組立, ロール成形

\section{1 序}

建築物の終局耐震設計法では, 地震によるエネルギー 入力に対する構造物の抵抗は，エネルギー吸収能力とし てとらえることができる11,2)。終局耐震性能は, 地震入力 エネルギーに対し骨組に十分なエネルギー吸収能力を付 与すると同時に, 地震外乱時に骨組の中の特定層のみに 過大な変形が生じることなく，良好な応答性状が得られ るように，適切な動力学特性を骨組に与えておくことで 確保される。

剛性モーメントフレームの場合, エネルギー吸収能力 は柱, 梁部材及び柱梁接合部パネル部の塑性変形能力に 期待される。半剛接モーメントフレームの場合，部材の 塑性化に柱梁接合部の塑性化がエネルギ一吸収源として 加わる。角形鋼管を柱として用いた場合, 梁フランジの 応力を柱に伝達するために, 梁フランジ位置において角
形鋼管柱の内側ないし外側に水平ダイアフラムを溶接 し，接合部を剛にすることが一般的である。一方，ダイ アフラムを設けない場合, 梁材端の曲げモーメントは柱 フランジ板の面外変形抵抗によって柱に伝達される。こ の場合, 柱フランジの面外変形, 曲げ降伏により柱梁接 合部は半剛接になり，接合部の耐力は主に柱フランジの 板厚に支配される。従って，柱フランジの板厚がある程 度確保されれば，接合部は地震に抵抗するために十分な エネルギー吸収能力を発揮し得る3) 7)。柱梁接合部に多 イアフラムを設ける必要がなければ，角形鋼管のモーメ ントフレームへの適用は施工面から見て極めて容易にな る。

筆者等は角形柱一H 形梁接合部に特別な補強を設け ない場合の無補強半剛接接合部試験体についての力学的 挙動を明らかにする目的で，単調載荷及び正負繰返し漸

\footnotetext{
* 東京大学建築学科 教授・工博

** 東京大学建築学科 大学院生.工修

*** 住友金属工業 工博

***** 住友金属工業 工修

***** 東京大学建築学科 助手. 工博
}

Prof., Dept. of Architecture, Faculty of Eng., Univ. of Tokyo, Dr. Eng. Graduate Student, Dept. of Architecture, Faculty of Eng., Univ. of Tokyo, M. Eng.

Dept. of Construction Eng., Sumitomo Metal Ind. Ltd., Dr. Eng. Dept. of Structural Eng., Sumitomo Metal Ind. Ltd., M. Eng. Research Assoc., Dept. of Architecture, Faculty of Eng., Univ. of Tokyo, Dr. Eng. 
増載荷試験を行った。本論文は, 既往の研究を参照しつ つ，実験結果に基づいて，各パラメータによる無補強接 合部の降伏耐力, 初期剛性及び 2 次剛性の変化などその 力学的特性に関わる基礎的資料を提供するものである。

\section{2 実験}

実験では，溶接成形角形鋼管とロール成形角形鋼管を 柱として用いた。溶接成形角形鋼管を柱として用いた場 合は， 3 点曲げと逆対称曲げによる加力を行った。ロー ル成形角形鍋管を用いた場合は 3 点曲げ方式である。

実験 I では溶接成形角形鋼管を柱として用いた場合 に, 柱と梁の形状による力学的挙動への影響を調べるこ とを目的とした。実験 I の加力は 3 点曲げ方式による。 実験 II では，溶接成形角形鋼管を用い，逆对称曲げの条 件下で繰り返し加力を行った。実験IIIでは，ロール成形 角形鋼管を柱として用いた場合の接合部の挙動を調べ, 実験 I の結果と比較する。また，実験 IIにおいて，柱の 曲げ降伏，接合部パネルのせん断降伏は起こらない。

(1) 実験 I：溶接成形角形鋼管柱を対象とした実験

無補強溶接成形角形鋼管柱一H 形断面梁接合部の耐 力及び剛性に与える柱フランジの板厚, 柱フランジ幅に 対する梁フランジ幅の比及び柱に作用する軸力比の影響 を調へることを目的とした。試験体は内柱部を想定した 十字型部分骨組で，その形状及び梁フランジの溶接部の 詳細を図 1 に示す。

各試験体の寸法及び JIS 1 号試験片から得られた素材 の機械的性質を表 1 に示す。用いた鋼材は柱, 梁共に SM490である。柱フランジの板厚は $12 \mathrm{~mm}, 16 \mathrm{~mm}, 19$ $\mathrm{mm}, 22 \mathrm{~mm}, 32 \mathrm{~mm}$ であり，32mm を除いては梁より接 合部が先に降伏するように設計した。

実験装置を図 2 に示す。柱に軸力が作用しない場合, 油圧式2,000tonf 試験機を用い, 柱部に集中荷重を加之 た。変形の測定には図 2 (a)に示す位置に取り付けた変位 計を用い, 柱部の鉛直変位, パネルゾーンの変形を計測
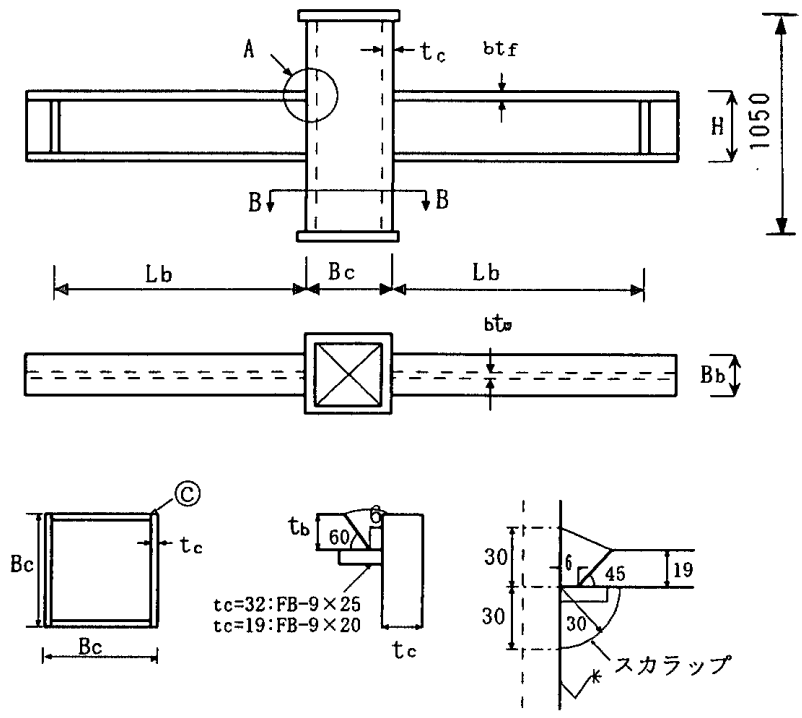

B - B 断面

(C) 部祥稩

A 部㲔种

図 1 試験体の形状（実験 I）

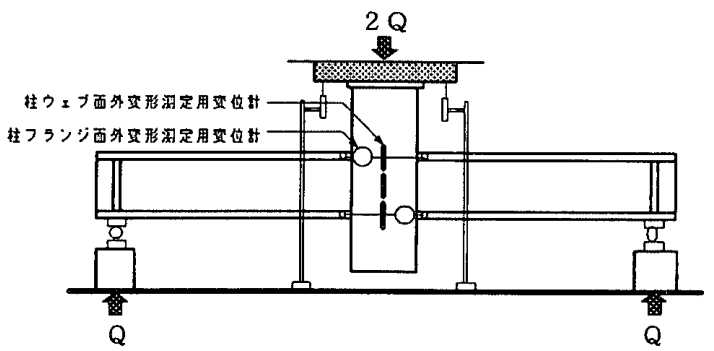

（a）軸力が作用しない場合 $\mathrm{N}+2 \mathrm{Q}$

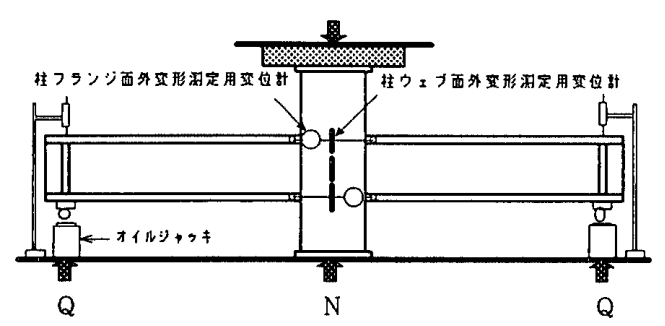

（b）軸力が作用する場合

図 2 実験装置（実験 I）

表 1 試験体の寸法及び機械的性質（実験 I）

\begin{tabular}{|c|c|c|c|c|c|c|c|c|c|c|c|}
\hline \multirow{3}{*}{ 試験体 } & \multicolumn{4}{|c|}{$\begin{array}{lll}\text { 形 } & \text { 状 }(\mathrm{mm})\end{array}$} & \multicolumn{6}{|c|}{ 機械的性質 $\left(\mathrm{t} / \mathrm{cm}^{2}\right)$} & \multirow{3}{*}{$\begin{array}{l}\text { 軸力比 } \\
\mathrm{N} / \mathrm{N}_{\mathrm{y}}\end{array}$} \\
\hline & \multicolumn{2}{|c|}{ 柱(SM490) } & \multicolumn{2}{|l|}{ 梁(SM490) } & \multicolumn{2}{|c|}{ 柱 } & \multicolumn{4}{|c|}{ 梁 } & \\
\hline & $\mathrm{B}_{\mathrm{c}}$ & $t_{c}$ & $\mathrm{H} \times \mathrm{B}_{b} \times{ }_{b} t_{W} \times{ }_{b} t_{f}$ & $L_{b}$ & $\sigma_{\mathrm{y}}$ & $\sigma_{u}$ & $f_{y}$ & $\mathrm{f}_{\mathrm{u}}$ & ${ }_{W} \sigma_{Y}$ & ${ }_{\mathrm{w}} \sigma_{\mathrm{u}}$ & \\
\hline No. 1 & 350 & 12 & $300 \times 200 \times 12 \times 19$ & 1325 & 3.450 & 5.429 & 3.612 & 5.252 & 3. 797 & 5.635 & 0 \\
\hline No. 2 & 350 & 16 & $300 \times 200 \times 12 \times 19$ & 1325 & 3. 383 & 5.357 & 3. 612 & 5.252 & 3. 797 & 5. & 0 \\
\hline No. 3 & 350 & 19 & $300 \times 200 \times 12 \times 19$ & 1325 & 3. 550 & 5. 292 & 3. 612 & 5.252 & 3. & & 0 \\
\hline №. 4 & 350 & 19 & $300 \times 200 \times$ & 1325 & 3. 550 & 5. 292 & 612 & 5. 252 & 3. 797 & & 0 \\
\hline No. 5 & 350 & 22 & $300 \times 200 \times 12 \times 19$ & 1325 & 3.456 & 5. 308 & 3. 612 & 5. 252 & 3. 797 & 5. & 0 \\
\hline №. 6 & 350 & 32 & $300 \times 200 \times 12 \times 19$ & 1325 & 3.367 & 5.308 & 3.612 & 5. 252 & 3. 797 & 5.635 & 0 \\
\hline No. 7 & 350 & 19 & $300 \times 250 \times 12 \times 19$ & 1325 & 3.550 & 5.292 & 3.612 & 5.252 & 3. 797 & 5.635 & 0 \\
\hline No. 8 & 350 & 19 & $300 \times 150 \times 12 \times 19$ & 1325 & 3.550 & 5.292 & 3.612 & 5.252 & 3.797 & 5.635 & 0 \\
\hline No. 9 & 350 & 19 & $300 \times 200 \times 12 \times 19$ & 1325 & 3.550 & 5.292 & 3.612 & 5.252 & 3.797 & 5.635 & 0.5 \\
\hline No. 10 & 350 & 19 & $300 \times 200 \times 12 \times 19$ & 1325 & 3.550 & 5.292 & 3.612 & 5.252 & 3. 797 & 5.635 & 0.8 \\
\hline
\end{tabular}


した。

柱に軸力が作用する場合は, 油圧式 2,000tonf 試験機 で柱部に軸力をかけた上で, オイルジャッキにより梁端 にせん断力を加えた。変形の計測は図 2 (b)に示す位置に 取り付けた変位計を用い，加力点位置における変位とパ ネルゾーンの変形を計測した。加力は，一方向単調载荷 としたが, No. 3 試験体と同じ断面を有するNo. 4 試験 体のみ繰返し载荷を行った。

繰り返し載荷は変位制御で, 載荷振幅は図 3 に示すも のである。困中の累積塑性変形倍率 $(\eta)$ を次式のように 定義する。

$$
\eta=\left(\delta_{\max }-\delta_{y}\right) / \delta_{y}
$$

$$
\text { ここで, }
$$

$\delta_{\max }:$ 各サイクルでの最大変形

$\delta_{y}:$ 降伏変形

(2) 実験 II：加力方法の影響を調べるための実験

加力方法が無補強接合部に与える影響を調べるため, 実験 I の試験体のうち No. 3, No. 6 試験体と同じ断面 の柱と梁部材を用いて試験体を製作した。試験体の形状 及び実験装置を図 4 に示す。試験体の寸法及び素材の機 械的性質を表 2 に示す。なお，柱断面の詳細と柱と梁つ ランジの溶接部の詳細は実験 I と同じである。加力方法 としては, オイルジャッキにより梁端で逆方向にせん断 力を加之た。加力は正負繰り返し漸増振幅載荷とした。 載荷のパタンを図 3 に示す。

（3）実験III：冷間ロール成形角形鋼管柱を用いた場合に 対する実験

実験 I 及びIIでは，溶接成形角形鋼管を柱として用い たが，冷間ロール成形角形鋼管を柱として用いた場合の 成形法による影響を調へることを目的とした。試験体の 形状及び載荷パタンは基本的に実験 I と同じである。試 験体の寸法及び素材の機械的性質を表 3 に示す。表中の $r$ は断面の隅角部の曲率外半径である。実験で用いた鋼
材は，柱の場合 STKR490，梁の場合 SM490である。柱 に作用する軸力比及び梁の成を実験変数とした。実験装 置及び加力方法は実験 I と同じである。

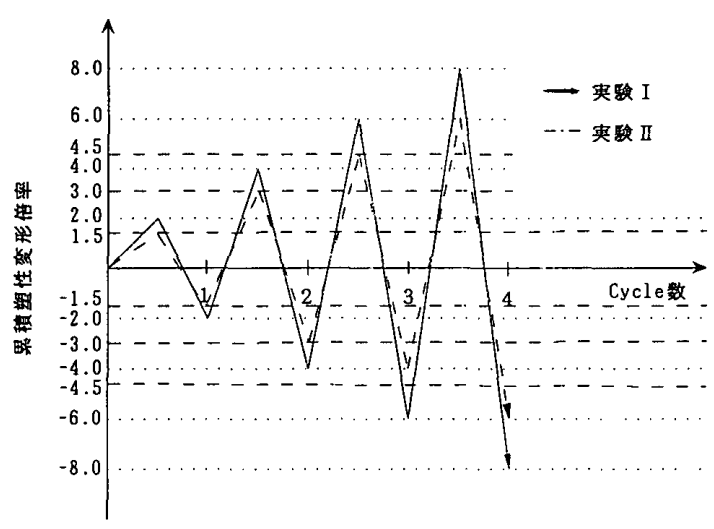

図 3 載荷振幅

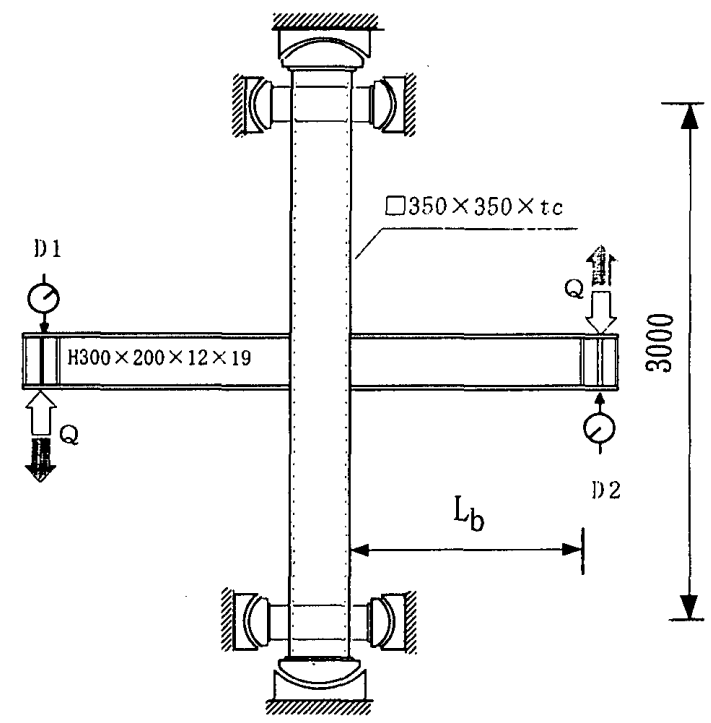

図 4 試験体の形状及び実験装置（実験 II）

\begin{tabular}{|c|c|c|c|c|c|c|c|c|c|c|c|}
\hline \multirow{3}{*}{ 試験体 } & \multicolumn{4}{|c|}{ 形 状 (mm) } & \multicolumn{6}{|c|}{ 機械的性質 $\left(\mathrm{t} / \mathrm{cm}^{2}\right)$} & \multirow{3}{*}{$\begin{array}{l}\text { 軸力比 } \\
\bar{N} / N_{y}\end{array}$} \\
\hline & \multicolumn{2}{|c|}{ 柱(SM490) } & \multicolumn{2}{|l|}{ 梁(SH490) } & \multicolumn{2}{|c|}{ 柱 } & \multicolumn{4}{|c|}{ 梁 } & \\
\hline & $\mathrm{B}_{\mathrm{C}}$ & $t_{c}$ & $\mathrm{H} \times \mathrm{B}_{b} \times{ }_{b} t_{w} \times_{b} t_{f}$ & $\mathrm{~L}_{\mathrm{b}}$ & $\sigma_{\mathrm{y}}$ & $\sigma_{\mathrm{u}}$ & $\sigma_{\mathrm{y}}$ & $f^{\sigma}$ & ${ }_{\mathrm{w}} \sigma_{\mathrm{y}}$ & ${ }_{\mathrm{w}} \sigma_{\mathrm{u}}$ & \\
\hline No. 11 & 350 & 19 & $300 \times 200 \times 12 \times 19$ & 1325 & 3.55 & 5.29 & 3.61 & 5.25 & 3.80 & 5.64 & 0 \\
\hline No. 12 & 350 & 32 & $300 \times 200 \times 12 \times 19$ & 1325 & 3. 37 & 5. 31 & 3. 61 & 5.25 & 3.80 & 5.64 & 0 \\
\hline
\end{tabular}

表 2 試験体の寸法及び機械的性質（実験 II）

\begin{tabular}{|c|c|c|c|c|c|c|c|c|c|c|c|c|}
\hline \multirow{3}{*}{ 試験体 } & \multicolumn{5}{|c|}{ 形 状 (mm) } & \multicolumn{6}{|c|}{ 機械的性質 $\left(\mathrm{t} / \mathrm{cm}^{2}\right)$} & \multirow{3}{*}{$\mid \begin{array}{l}\text { 軸力比 } \\
\mathrm{N} / \mathrm{N}_{\mathrm{y}}\end{array}$} \\
\hline & \multicolumn{3}{|c|}{ 柱(STKR490) } & \multicolumn{2}{|l|}{ 梁(SH490) } & \multicolumn{2}{|c|}{ 柱 } & \multicolumn{4}{|c|}{ 梁 } & \\
\hline & $\mathrm{B}_{c}$ & $t_{c}$ & $r$ & $\mathrm{H} \times \mathrm{B}_{h} \times_{h} \mathrm{t}_{w} \times_{h} t_{f}$ & $L_{b}$ & $\sigma_{\mathrm{y}}$ & $\sigma_{11}$ & $f \sigma_{y}$ & $f_{\mu}$ & ${ }_{w} \sigma_{\mathrm{y}}$ & ${ }_{w} \sigma_{\mu}$ & \\
\hline No. 13 & 350 & 18 & 67 & $300 \times 200 \times 12 \times 19$ & 1325 & 5.80 & 6.05 & 3.71 & 5.26 & 3.81 & 5.17 & 0 \\
\hline No. 14 & 350 & 18 & 67 & $300 \times 200 \times 12 \times 19$ & 1325 & 5.80 & 6.05 & 3. 71 & 5. 26 & 3.81 & 5. 17 & 0.5 \\
\hline No. 15 & 350 & 18 & 67 & $300 \times 200 \times 12 \times 19$ & 1325 & 5.80 & 6.05 & 3. 71 & 5.26 & 3.81 & 5.17 & 0.8 \\
\hline No. 16 & 350 & 18 & 67 & $600 \times 200 \times 12 \times 19$ & 1325 & 5.80 & 6.05 & 3.66 & 5.44 & 3.70 & 5.19 & 0 \\
\hline
\end{tabular}

表 3 試験体の寸法及び機械的性質（実験 III） 


\section{3 実験結果}

各実験変数に伴うモーメント一回転角関係 $(M-\theta$ 関 係)の変化を図 7 ～図14に示す。縦軸の $M$ は接合部位置 においての曲げモーメントであり，横軸の $\theta$ は梁の材端 部材角である。ただし，繰り返し載荷を行った試験体の 骨格曲線は図 5 に示す方法で得られた8)。

実験結果の一覽を表 4 に示す。ここで，接合部の降伏 耐力は General Yield Point 法（図 6 ）によって求めた 值である。即ち，原点から初期剛性 $\left(K_{1}\right)$ の1/2.5倍勾配 を持つ線を引き，実験值との交点の接線を 2 次剛性 $\left(K_{2}\right)$ とし，初期剛性と 2 次剛性を表す線の交点を降伏耐力と

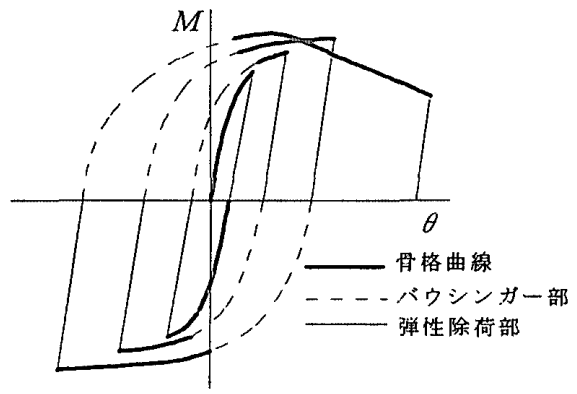

図 5 繰返し荷重下における $M-\theta$ 関係

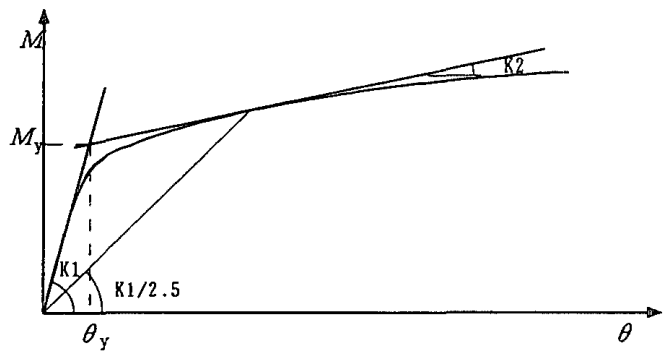

図6 降伏酎力の決定法

表 4 実験結果

\begin{tabular}{|l|c|c|r|r|r|}
\hline 試験体 & $\begin{array}{c}\mathrm{M}_{\mathrm{y}} \\
(\mathrm{t} \cdot \mathrm{m})\end{array}$ & $\begin{array}{c}\theta_{\mathrm{y}} \\
(\mathrm{rad})\end{array}$ & $\begin{array}{l}\mathrm{K}_{1} \\
\mathrm{t} \cdot \mathrm{m} / \mathrm{rad}\end{array}$ & $\begin{array}{l}\mathrm{K}_{2} \\
\mathrm{t} \cdot \mathrm{m} / \mathrm{rad}\end{array}$ & $\mathrm{K}_{2} / \mathrm{K}_{1}$ \\
\hline No. 1 & 6.85 & 0.025 & 275.6 & 61.4 & 0.22 \\
No. 2 & 12.64 & 0.018 & 700.5 & 79.0 & 0.11 \\
No. 3 & 16.62 & 0.016 & 1020.0 & 91.3 & 0.08 \\
No. 4 & 16.59 & 0.016 & 1018.3 & 91.1 & 0.09 \\
No. 5 & 22.74 & 0.017 & 1330.8 & 105.3 & 0.08 \\
No. 6 & 38.94 & 0.015 & 2659.8 & 231.7 & 0.08 \\
No. 7 & 20.84 & 0.012 & 1704.7 & 150.9 & 0.09 \\
No. 8 & 14.26 & 0.020 & 716.3 & 73.7 & 0.10 \\
No. 9 & 14.58 & 0.012 & 1176.2 & 96.6 & 0.08 \\
No. 10 & 10.20 & 0.011 & 965.6 & 45.6 & 0.04 \\
No. 11 & 16.83 & 0.015 & 1158.2 & 94.8 & 0.08 \\
No. 12 & 39.35 & 0.014 & 2773.9 & 235.3 & 0.08 \\
No. 13 & 25.40 & 0.021 & 1206.1 & 122.9 & 0.10 \\
No. 14 & 19.54 & 0.013 & 1490.5 & 150.9 & 0.10 \\
No. 15 & 15.57 & 0.014 & 1120.1 & 80.8 & 0.07 \\
No. 16 & 55.44 & 0.014 & 3934.4 & 549.5 & 0.14 \\
\hline
\end{tabular}

した。

実験終了時の試験体の様子を写真 1 に示す。溶接成形 角形鋼管柱を用いた実験 I 及び実験 II（写真 2 (a)) では, 全試験体ともに降伏耐力を越之た後，梁の引張側フラン ジ端部の溶接止端部位置において，柱母材に延性亀裂が 発生したが，それによる荷重の低下は見られなかった。 一方，ロール成形角形鋼管柱を用いた実験IIIでは，軸力 が作用しない試験体の場合，亀裂の発生状況は同様であ るが，最大荷重に至った瞬間，引張側フランジの溶接部 止端部の母材に発生した脆性亀裂によって，急激な耐力

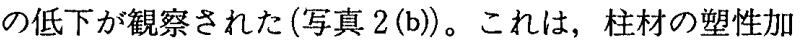
工による延性低下及び降伏比の上昇（96\%）に起因する と思われる。

また，繰り返し実験を行った場合(図14)，溶接成形角 形鋼管を柱として用いた，No. 4, No.11試験体は繰り返 し後期に前サイクルまでの載荷で進展した引張側の延性 亀裂が元に戻るまで荷重の增加はあまり見られず，変形 だけが進行する現象が現われた。

各実験変数による影響を次のようにまとめる。

(1) 柱フランジの板厚による影響

図 7 は柱フランジの板厚を実験変数として行った実験 から得られた $M-\theta$ 関係曲線である。柱の板厚が厚くな ることに伴って降伏耐力と初期剛性が大きくなってい

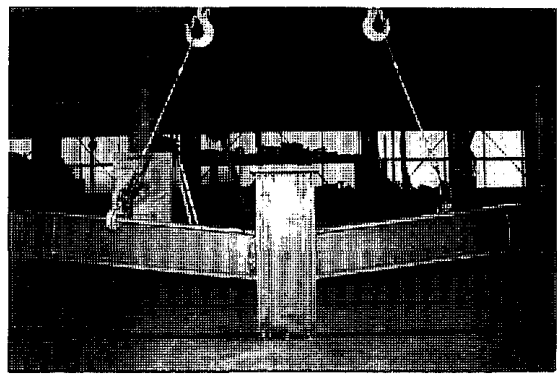

写真 1 実験終了時の試験体の状況

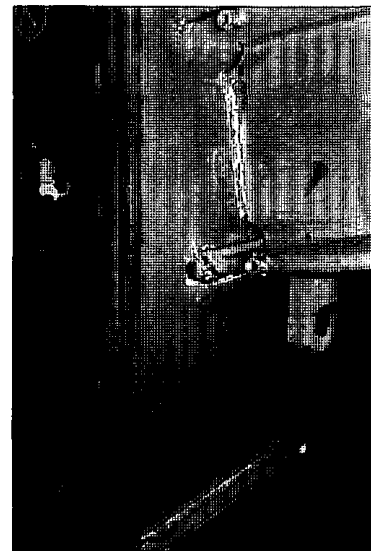

（a）延性亀裂（溶接成形）

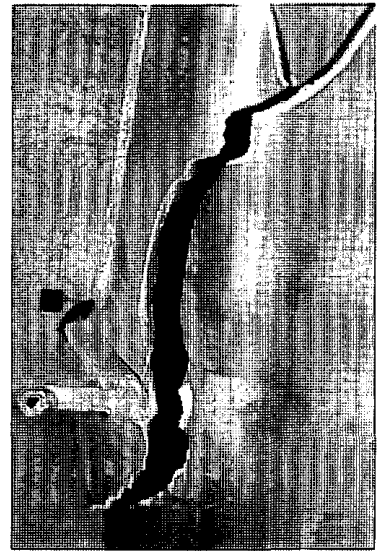

（b）脆性龟裂（ロール成形）
写真 2 引張側フランジの溶接止端部の龟裂 
る。

(2) 柱フランジ幅に対する梁フランジ幅の影響

柱フランジの幅を一定にし，梁フランジの幅を変えて 行った実験結果を図 8 に示す。柱フランジ幅に対する梁 フランジ幅の比が大きくなることに伴って，降伏酎力及 び初期剛性が増加している。

(3) 柱に作用する軸力比の影響

柱に作用する軸力を実験変数として行った実験から得 られた $M-\theta$ 関係曲線を図 9 図10に示す。図 9 は溶接 成形角形鋼管柱を用いた場合（実験 I ）であり，図10は ロール成形角形鋼管柱を用いた試験体の場合（実験III） である。柱に軸力が作用する場合，実験 I では柱部に短

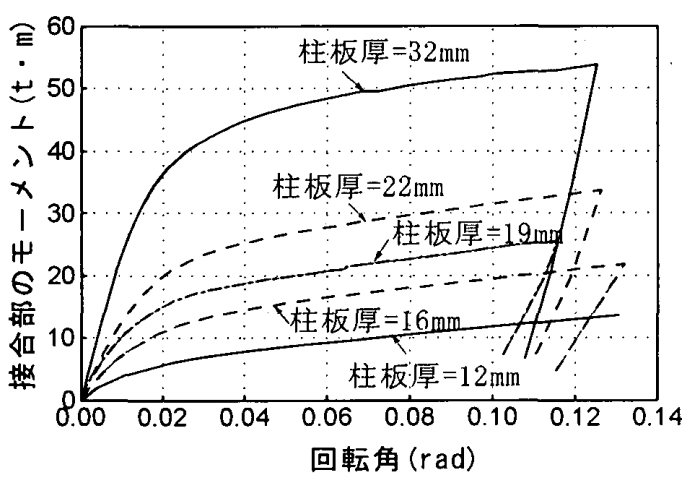

図 7 柱板厚の影響

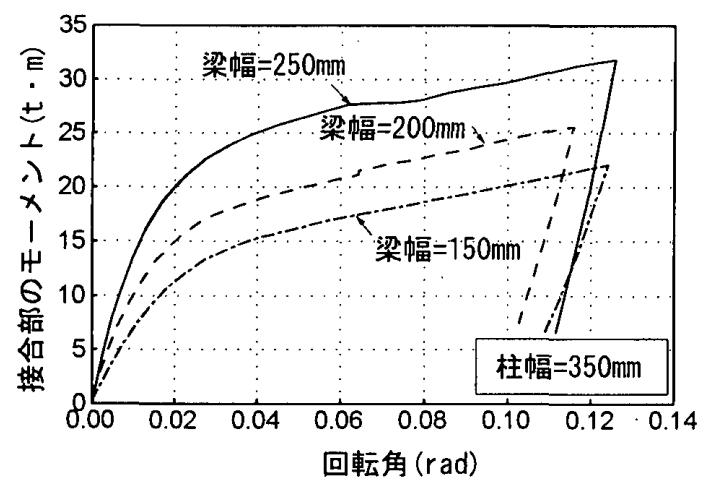

図 8 梁フランジ幅の影響

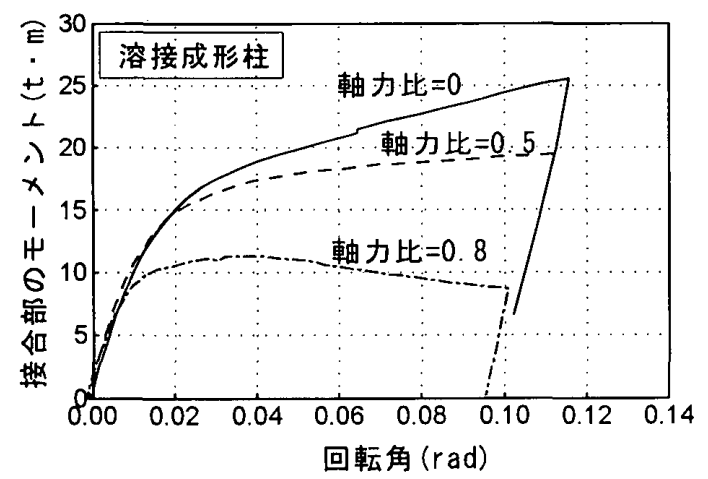

図 9 軸力の変化による影響（実験 I ）

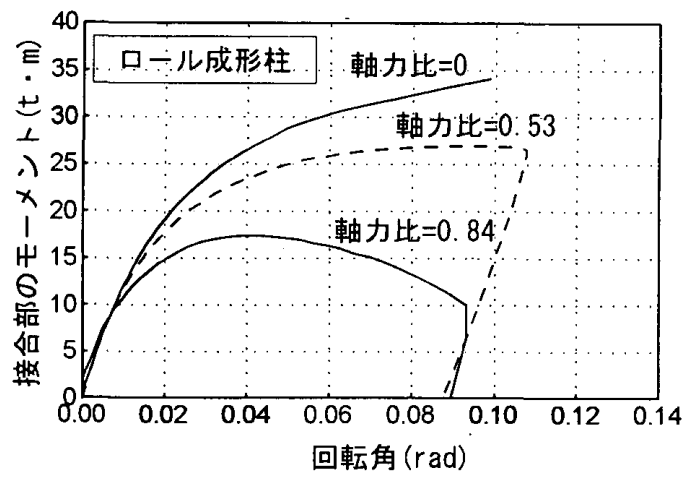

図10 軸力の変化による影響（実験III）

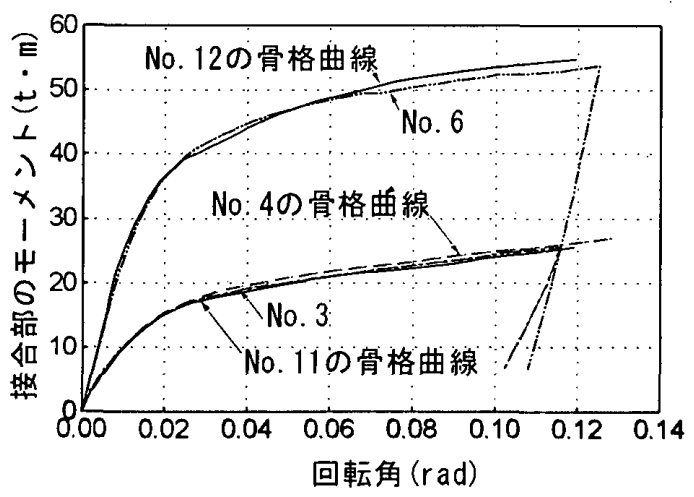

図11 加力方法の影簧

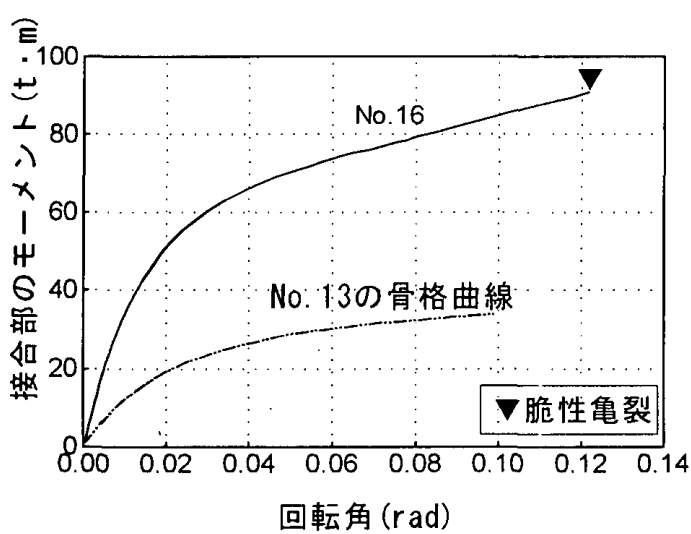

図12 梁成の影響

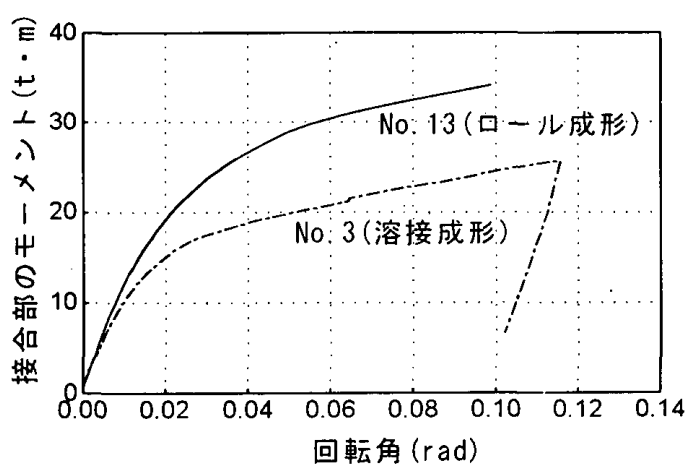

図13 柱の成形法の影響 


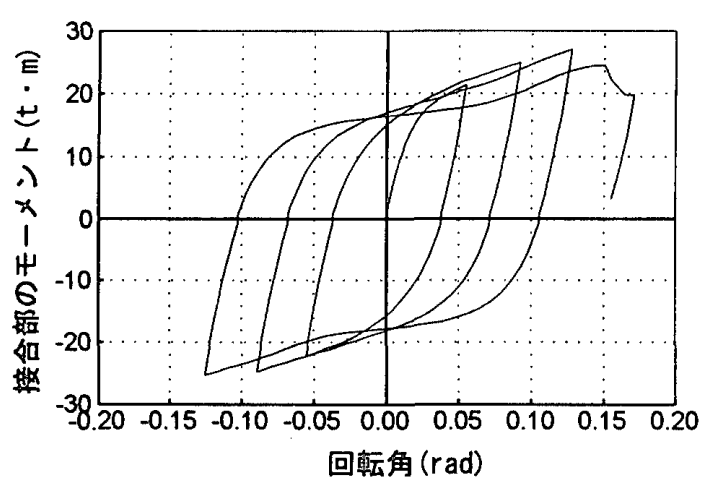

(a) No. 4

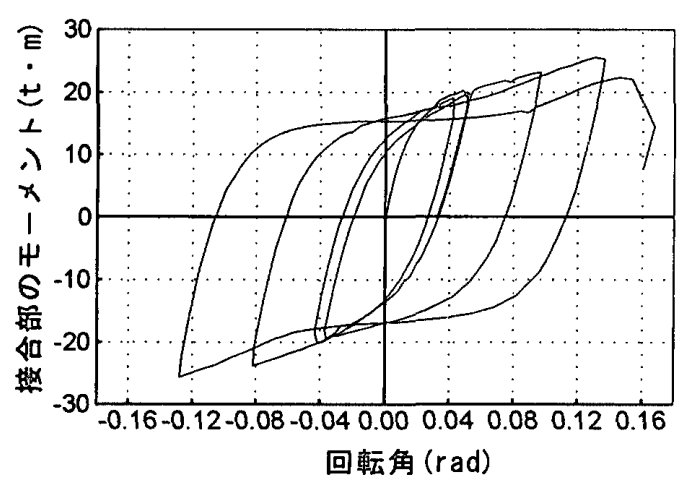

(b) No. 11

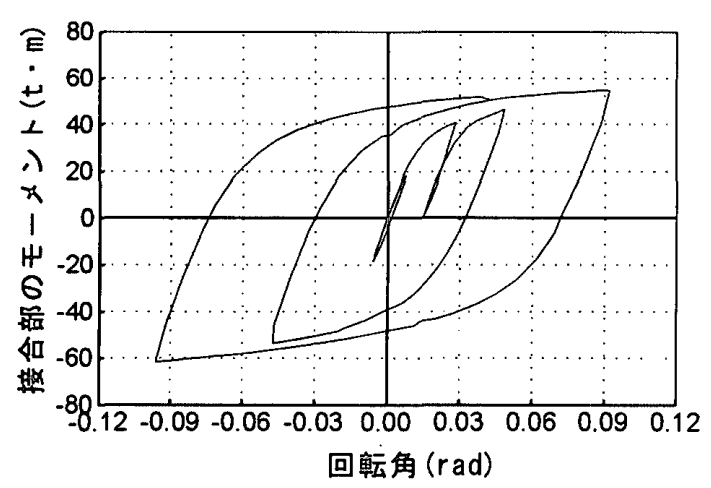

(c) No. 12

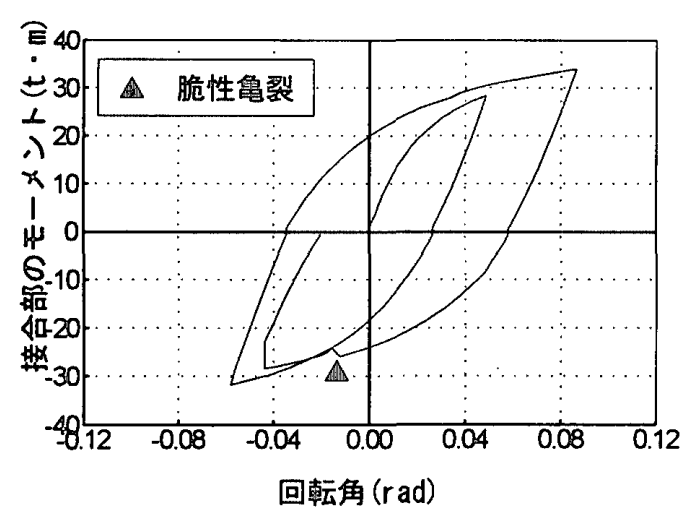

(d) No. 13

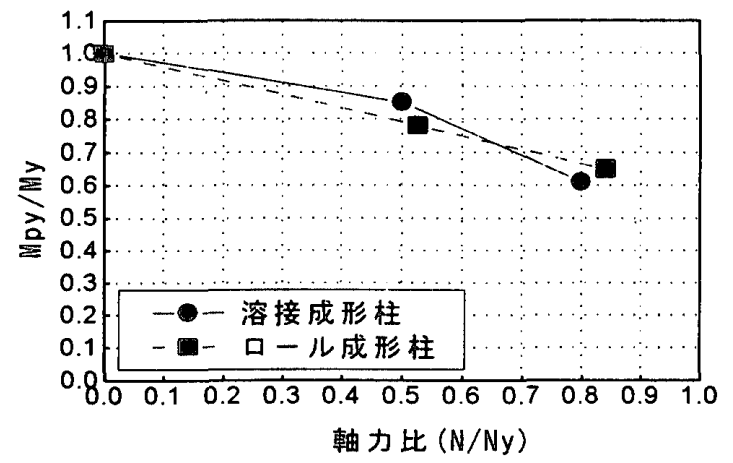

図15軸力による降伏耐力の低下率

柱圧縮試験から得られた降伏耐力 (931tonf)の0.5倍, 0.8 倍の軸力を加えた状態で，梁端にオイルジャッキで加力 した。一方, 実験IIIでは柱部に素材の引張試験から得ら れた降伏耐力 ( 1,350 tonf) の0.526倍，0.842倍の軸力を 加えた状態で，梁端にオイルジャッキで加力した。ただ し，軸力が作用しないNo.13試験体については繰り返し 実験を行ったので，その骨格曲線と比較した。

軸力の作用による降伏耐力の低下率を図15に示す。柱 の形状によらず，柱に作用する軸力による降伏耐力の低 下率はほほ同じ様相を見せている。

(4) 加力方法の影響

加力方向が無補強接合部の $M-\theta$ 関係に与之る影響 を調べるため，実験II試験体に对する実験結果と同じ断 面を有する実験 Iの No. 3 と No. 6 試験体に対する実験 結果と比較して図11に示す。実験II試験体は梁端部で逆 方向に加力した場合であり, 実験 I は梁端部で 3 点曲げ 実験により対称に加力した場合である。ただし，繰返し 実験を行ったNo. 4 及びNo.12試験体については図 5 の ような方法で骨格曲線部分を取ったものである。各試験 体に对して，加力方向による差は認められなかった。こ の結果から, 外力条件の違いによる接合部の挙動への影 響はほとんどないことが分かった。

(5) 梁成の影響

図12はロール成形角形鋼管柱を用いて，梁の成を実験 変数とした場合の $M-\theta$ 関係曲線である。No.13試験体 は負側で前サイクルの耐力まで至ってない状態で脆性亀 裂が発生した。梁の成が大きいNo.16試験体が降伏耐力 及び初期剛性が大きいことが分かる。

(6) 柱成形法の影響

図13は柱の断面として溶接成形角形断面を用いた場合 とロール成形角形断面を用いた場合の実駼結果を比較し たものである。柱として用いた母材の降伏点がロール成 形角形鋼管の方が大きいので，降伏耐力も大きくなって いる。

図14繰り返し奏験結果 


\section{4 復元力特性の定式化}

4-1 復元力特性の形態

繰り返し実験を行った試験体（図14）を対象に，サイ クルの進展による降伏モーメントの低下の椂相を図16に 示す。縦軸は図 6 の方法で求めた各サイクルでの降伏 モーメント $\left({ }_{B} M_{y}\right)$ を最初サイクルの降伏モ一メント $\left(M_{y}\right)$ で無次元化した。横軸は各サイクルの始点での部材 回転角の絶対值 $\left.{ }_{B} \theta\right)$ を $\theta_{x}\left(=M_{y} / K_{2}\right)$ で無次元化した。 図中の $K_{2}$ は図 6 に示す方法で奏験から得られた 2 次剛 性である。図から，各サイクルでの降伏モーメントと ${ }_{B} \theta$ との関係は, 正負側に関わらず次式で表すことができる ことが分かる。

$$
{ }_{B} M_{y}=M_{y}-K_{2} \cdot{ }_{B} \theta
$$

また，サイクルの進展による弾性域の初期剛性と除荷 部の除荷剛性（図 5 参照）の変化は見られなかった。

従って, 無補強柱・梁接合部の $M-\theta$ 関係は図17に示 すような部材角によって降伏モーメントが変化する bilinear 型で定式化することができることが分かった。

\section{4-2 降伏耐力}

4-2-1 軸力が作用しない場合

柱・梁接合部が降伏耐力に達した時の耐荷機構を図18 のように仮定すると，接合部の降伏モーメントは次式で 与えられる。

$$
M_{0 y}={ }_{c} P_{y} \cdot h_{c}=Q_{0 y} \cdot L_{b}
$$

ここで,

$L_{b}:$ 梁の長さ

$h_{c}:$ 梁フランジの中心間距離

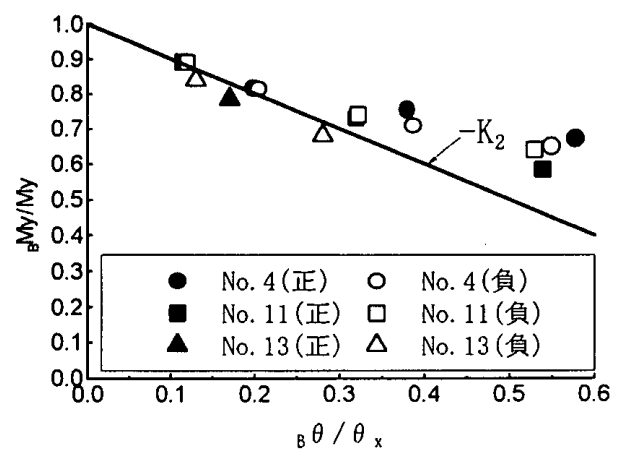

図16 各サイクルの降伏モーメント

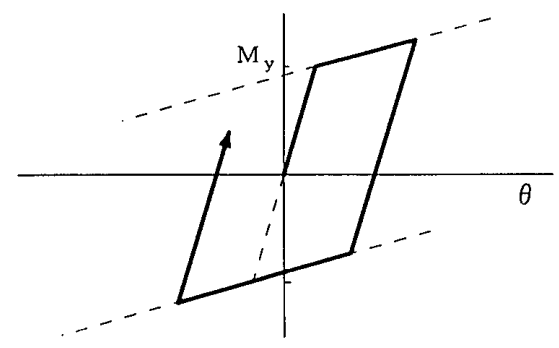

図17 復元力特性モデル
${ }_{c} P_{y}:$ 接合部の降伏酎力

$Q_{0 y}:$ 梁に作用する降伏時のせん断力

柱・梁接合部の降伏耐力を求める方法として，降伏線 理論を用いた方法が提案されている31,4),12)。森田等は, 梁 フランジ端部に生じる応力集中により, 降伏応力に達し ている梁端部のなす仕事に着目した降伏メカニズムを設 定し，接合部の降伏耐力を評価している。上界定理であ る降伏線理論による解は実現象を厳密に説明し得るもの ではないが，接合部の耐荷機構における各変数が果たす 役割を表現し得るものと考えられる。そこで，実験式を 導くためのより簡単なモデルとして図19に示す降伏メカ ニズムを採用する。ただし，ロール成形角形鋼管を用い た場合は断面隅角部の湾曲の影響を無視し，溶接成形角 形鋼管と同じ降伏メカニズムを有することにした。

柱フランジの単位長さ当たりの降伏モーメント $\left(M_{p}\right)$ を次のように仮定する。

$$
M_{p}=\frac{t_{c}^{2} \cdot{ }_{c} \sigma_{y}}{4}
$$

ここで,

$$
\begin{gathered}
{ }_{c} \sigma_{y}: \text { 柱フランジの降伏点 } \\
t_{c}: \text { 柱板厚 }
\end{gathered}
$$

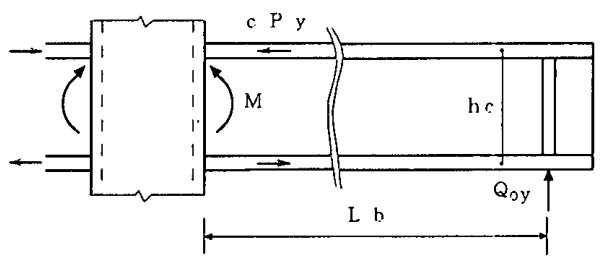

図18 耐荷機構の単純化

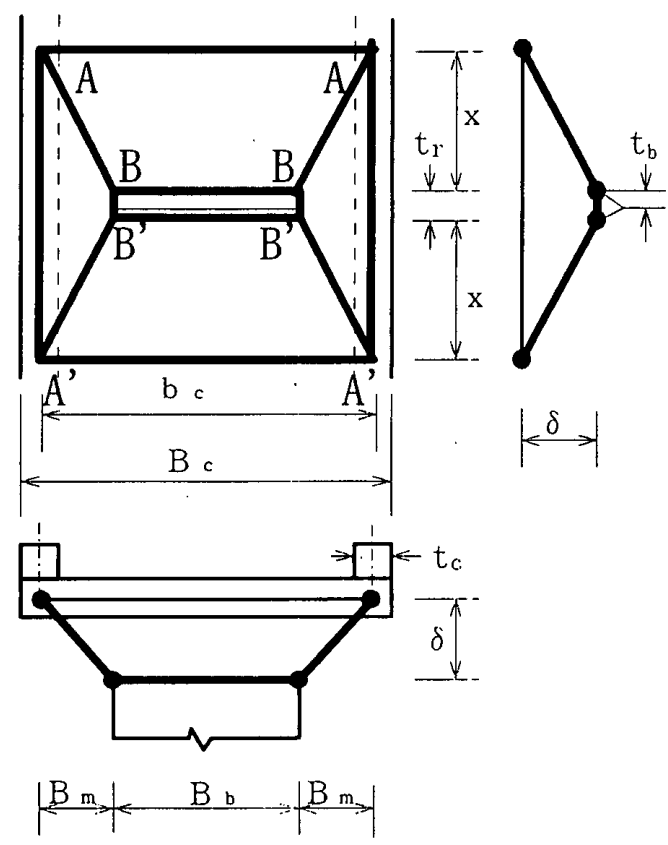

図19降伏メカニズム 
このモデルを用いれば，柱・梁接合部の降伏耐力 $\left({ }_{c} P_{y}\right)$ は次式で与えられる。

$$
{ }_{c} P_{y}=4 M_{p}\left(\frac{b_{c}}{x}+\frac{2 x+t_{r}}{B_{m}}\right)
$$

ここで，

$$
\begin{aligned}
B_{m} & =\frac{b_{c}-B_{b}}{2} \\
b_{c} & : \text { 柱フランジ中心間の距離 } \\
B_{b} & : \text { 梁フランジ幅 } \\
t_{r} & : \text { 梁フランジの溶接寸法 }
\end{aligned}
$$

${ }_{c} P y$ が最小となる条件 $(\partial P / \partial x=0)$ より，未知数 $x$ は 次式で表すことができる。

$$
x=\sqrt{B_{m} \cdot b_{c} / 2}
$$

上式を(5)式に代入すると

$$
{ }_{c} P_{y}=2{ }_{c} \sigma_{y} t_{c}^{2}\left(2 \sqrt{\frac{b_{c}}{b_{c}-B_{b}}}+\frac{t_{r}}{b_{c}-B_{b}}\right)
$$

式(7)を式(3)に代入して得られた降伏モーメントの計算 值を実験值と比較して図20に示す。ただし, ${ }_{c} P_{y}$ が梁フラ ンジの引張耐力 $\left(={ }_{b} \sigma_{y} \cdot A_{f}\right)$ より大きいNo. 6 試験体に 对しては，接合部の降伏耐力は梁フランジの引張強度で 決められた。

溶接成形角形鋼管を柱として用いた場合の実験値は 印で，ロール成形角形鋼管を用いた場合は國印で示して いる。(7)式による計算値は，実験値を全般的に約 $30 \%$ 程 度過大評価している。また，森田等による降伏線理論に 基づいた文献3）の提案式で計算した值も実験值より平均 約 $25 \%$ 過大評価している。文献4)の提案式による計算結 果も実験値より過大評価 (平均15\%) する傾向があった。

そこで，(7)式のパラメータを用いて，最小自乗法によ

$\eta$ ，柱・梁接合部の降伏耐力の実験式(8)を求めた。

$$
{ }_{c} P_{y}=1.38_{c} \sigma_{y} t_{c}^{2}\left(2 \sqrt{\frac{b_{c}}{b_{c}-B_{b}}}+\frac{t_{r}}{b_{c}-B_{b}}\right)
$$

柱の断面形状によらず，(8)式による計算值は実験値と 良好な対応を見せている。

\section{4-2-2 軸力がある場合}

柱に軸力が作用する場合, 図19に示す各降伏線には,
図21のように $N \cos \theta$ の軸力と $N \sin \theta$ のせん断力が生 じる。従って, 各降伏面では曲げモーメントと軸力, せ ん断力が作用することになる。文献10)，11）では, 実験 結果から, せん断力が作用しても, 降伏モーメントには 影響を与えないことが指摘されている。従って, 降伏面 の降伏モーメントは, 曲げモーメントと軸力との関係の みに依存し，その関係は次式で表現できる11。

$$
\frac{M_{p c}}{M_{p}}+\left(\frac{N^{\prime}}{N_{y}}\right)^{2}=1
$$

$こ こ て ゙$,

$N^{\prime}=N \cos \theta$

$N$ : 柱に作用する軸力

$M_{p c}$ ：軸力が作用するときの単位長さ当たりの降伏 モーメント

$N_{y}:$ 柱の降伏軸力

ここで, 柱に軸力が作用するときの各降伏線に作用す る軸力 $N^{\prime}$ は次式のようになる。

$$
\text { 降伏線 }\left\{\begin{array}{l}
A A, \quad A^{\prime} A^{\prime}, \quad B B, \quad B^{\prime} B^{\prime}: N^{\prime}=N \\
A A^{\prime}, \quad B B^{\prime}: N^{\prime}=0 \\
A B, \quad A^{\prime} B^{\prime}: N^{\prime}=N\left(B_{m} / \sqrt{B_{m}^{2}+x^{2}}\right)
\end{array}\right.
$$

(10)式から求めた各降伏線の $N^{\prime}$ を(9)式に代入して求め た各降伏線の $M_{p c}$ を(4)式で定義した $M_{p}$ として用いる。 各降伏線の $M_{p c}$ を降伏線 $A A, A^{\prime} A^{\prime}, B B, B^{\prime} B^{\prime}$ の場合 は $M_{p 1}, A A^{\prime}, B B^{\prime}$ の場合は $M_{p 2}, A B, A^{\prime} B^{\prime}$ の場合 $M_{p 3}$ とする。

図19から, 未知数 $x_{1}$ の初期值として柱に軸力が作用し ないときの $x$ を採用すると，柱に軸力が作用するときの 降伏耐力 $\left(P_{y c}\right)$ は次式で与えられる。

$$
P_{y c}=2 M_{p 1} \frac{b_{c}+B_{b}}{x_{1}}+4 M_{p 2} \frac{x_{1}+t_{r}}{B_{m}}+4 M_{p 3} \frac{B_{m}^{2}+x_{1}^{2}}{B_{m} x_{1}}
$$

$P_{y c}$ が最小となる条件 $\left(\partial P / \partial x_{1}=0\right)$ より，未知数 $x_{1}$ は 次式になる。

$$
x_{1}=\sqrt{\frac{B_{m}\left(M_{p 1} b_{c}+M_{p 1} B_{b}+2 M_{p 3} B_{m}\right)}{2\left(M_{p 2}+M_{p 3}\right)}}
$$

ただし，軸力が作用するときの $x_{1}$ は $x$ と必ずしも一 致しない。従って，(10)から得られた降伏モ一メントを(12)

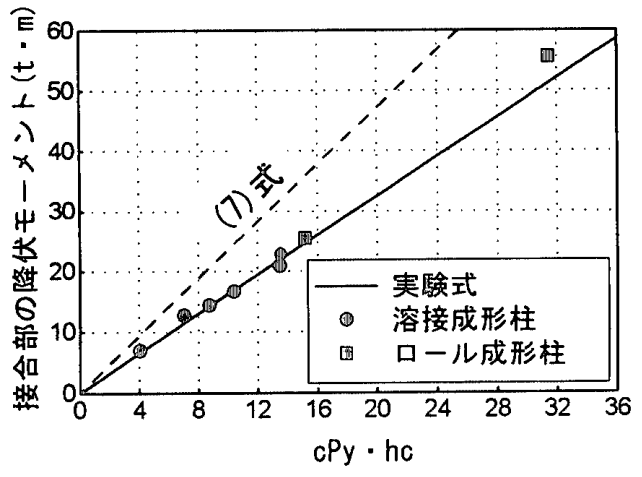

図20計算値と実験值の比較

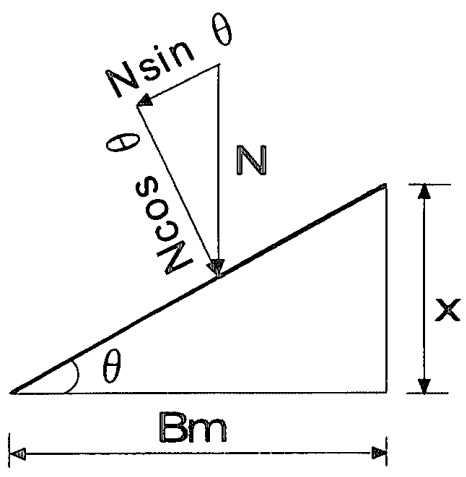

図21降伏線に作用する軸力 
式に代入し, 求めた未知数 $x_{1}$ の值が収束するまで繰り返 し計算を行う。

以上の手順で計算して求めた結果を図22に示す。試験 体の寸法を代入した場合の結果を太い破線で表した。実 験值とは良い对応を見せている。また，この方法では， 柱と梁の断面を変えた場合 $\left(B_{o} / b_{c}=0.3 \sim 0.9\right)$ も, 計算 結果には大きな差がないことが分かる。

従って, 柱に軸力が作用しない場合の接合部の降伏 モーメント $M_{0 y}$ に対する，軸力が作用する場合の接合部 の降伏モーメント $M_{p y}$ の関係は, 近似的に次式の上うに 表現できる。(図22中の太い実線)

$$
\left(\frac{M_{p y}}{M_{0 y}}\right)^{2}+\left(\frac{N}{N_{y}}\right)^{2}=1
$$

\section{4-3 初期剛性}

実験結果に基づいて, 柱と梁の幅の比 $\left(B_{b} / b_{c}\right)$, 柱の幅 厚比 $\left(b_{c} / t_{c}\right)$, 梁の形状比 $\left(h_{c} / B_{b}\right)$ をパラメータとしたと きの初期剛性との関係を図23に示す。図から初期剛性と この変数の間には線形関係が成り立っていることが分か る。実験値を用いて，最小自乗法により実験式(14)を得た。

$$
\begin{aligned}
& K_{1}=73 E I^{*}\left(\frac{B_{b}}{b_{c}}\right)^{3.5}\left(\frac{h_{c}}{B_{b}}\right)^{1.7}\left(\frac{b_{c}}{t_{c}}\right)^{0.5} \\
& \text { ここで, } \\
& E: \text { ヤング係数 }
\end{aligned}
$$

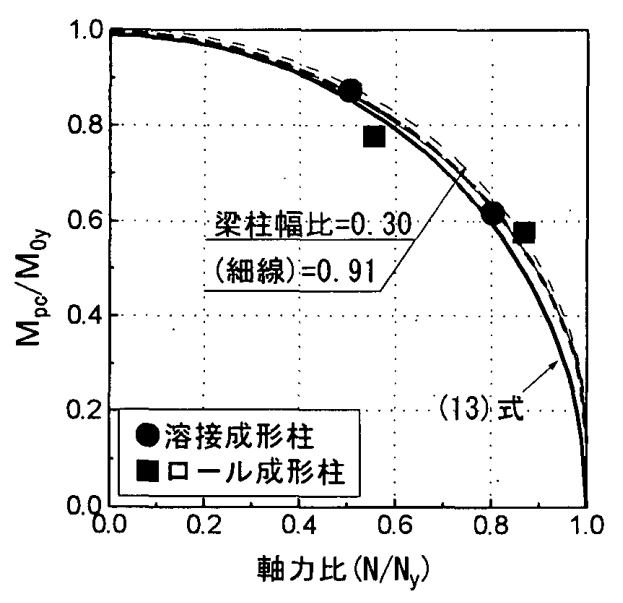

図22 軸力の作用による降伏耐力の低下

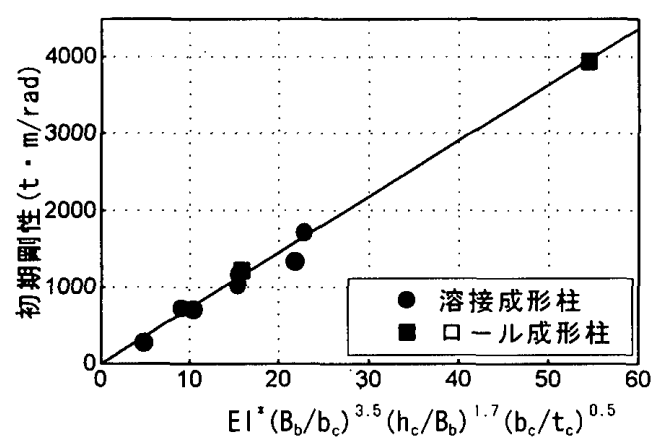

図23初期剛性

$$
I^{*}: t_{c}^{3} / 12
$$

また，柱に軸力が作用するときの初期剛性と軸力比と の関係を図24に示す。軸力比が約0.5近傍では軸力が作用 しないときより約 2 割ぐらい高い值を示しているが, 全 般的には柱に作用する軸力は初期剛性にあまり影響を与 えていないことが分かる。

\section{4-4 2 次剛性}

(1) 軸力が作用しない場合

柱に軸力が作用しない場合について柱と梁の幅の比 $\left(B_{b} / b_{c}\right)$, 柱の幅厚比 $\left(b_{c} / t_{c}\right)$, 梁の形状比 $\left(h_{c} / B_{b}\right)$ をパラ メータとしたときの 2 次剛性との関係を図25に示す。2 次剛性とこの変数の間には線形関係が成り立っている。 実験值を用いて, 最小自乗法により実験式(15)を得た。

$$
\begin{aligned}
& K_{02}=0.08 E I^{*}\left(\frac{B_{b}}{b_{c}}\right)^{3.6}\left(\frac{h_{c}}{B_{b}}\right)^{2.2}\left(\frac{b_{c}}{t_{c}}\right)^{2.0} \\
& \text { ここで, } \\
& E: \text { ヤング係数 } \\
& I^{*}: t_{c}^{3} / 12
\end{aligned}
$$

\section{(2) 軸力の影響}

柱に軸力が作用している場合, 軸力比の変化に伴う 2 次剛性の変化を図26に示す。四から，柱に軸力が作用す る場合の 2 次剛性（ $\left.K_{p 2}\right)$ は次式で表すことができる。

$$
K_{p 2}=\left(1-p^{4}\right) K_{02}
$$

$$
\text { ここで, }
$$

$$
p=N / N_{y}
$$

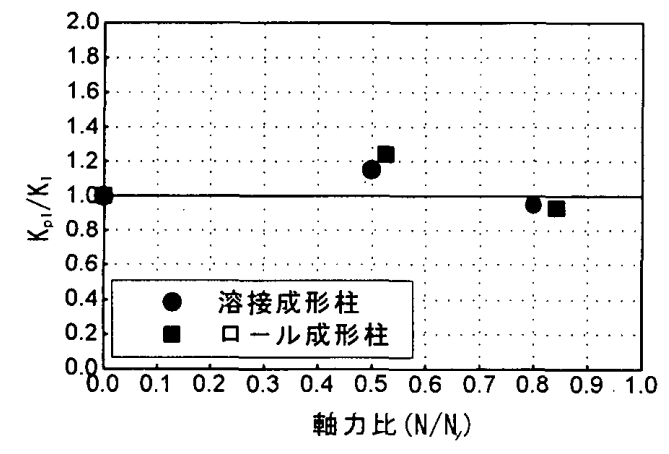

図24初期剛性と軸力比の関係

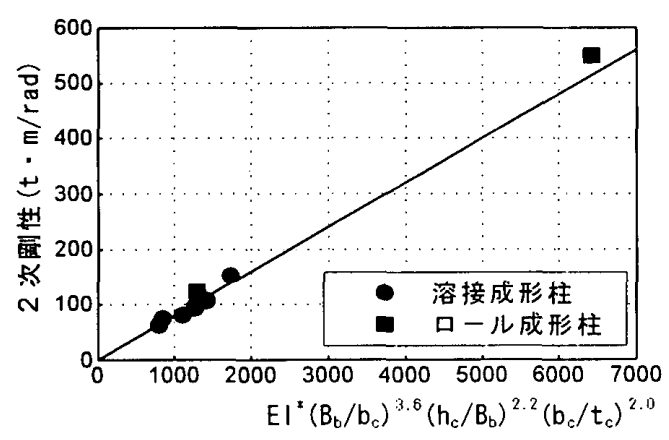

图252 次剛性 


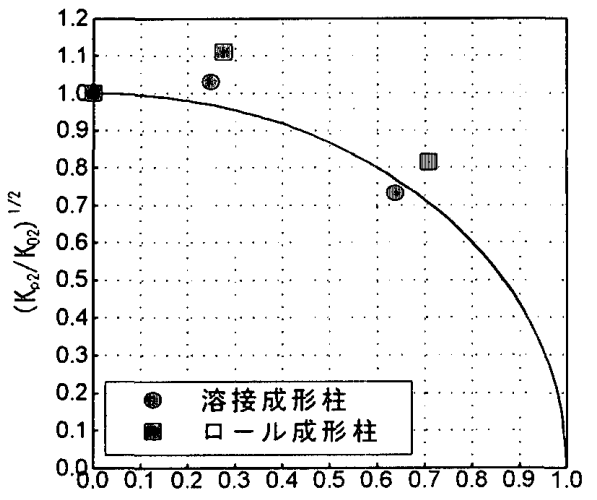

$\left(\mathrm{N} / \mathrm{N}_{\mathrm{v}}\right)^{2}$

図26 2 次剛性と軸力比の関係

$K_{02}$ : 軸力が作用しないときの 2 次剛性

\section{5 結論}

無補強柱・梁接合部に関する一連の実験に基づき，耐 震設計に関わる接合部の基本特性を明らかにし，その結 果を以下にまとめる。

1）各実験変数による影響を調べた結果，加力方向によ る $M-\theta$ 関係曲線の差は認められなかった。従って, 3 点曲げ実験による結果を地震荷重のような水平力が 作用すると想定した場合にも用いることができる。

2 ）無補強接合部の復元力特性は, 困17のように部材の 回転角の增加により降伏モーメントが低下するbilinear 型で定式化することができる。

3）降伏耐力は柱の成形法によらず，降伏線理論に基づ いて導いた実験式によって求めることができる。

4 ) 無補強接合部の初期剛性, 2 次剛性は, 柱幅に对す る梁幅の比, 柱の幅厚比, 梁の形状比をパラメータと して導いた実験式(14)及び(15)によって求めることができ る。

5) 降伏比が極めて高い冷間ロール成形角形鋼管にあっ
ては塑性化の進展に伴い脆性破壊を生ずる可能性があ る。

\section{参考文献}

1）秋山 宏：建築物の耐震極限設計, 東京大学出版会, 1987

2）日本建築学会：建築耐霞設計における保有耐力と変形能力 (1990)

3）森田耕治, 江波戸和正, 渡辺 仁, 山本 昇, 安田博和, 里見孝之：箱形断面柱一H 形断面はり接合部のタイアフ ラム補強に関する研究, 日本建築学会構造系論文集, 第388 号, pp.100 110, 1988.6

4) Koji Morita, Noburo Yamamoto and Kazumasa Ebato : Analysis on the strength of unstiffened beam flange to RHS column connections based on the conbined yield line model, Tubular Structures, Elsevier Applied Science, pp.164 171, 1989.9

5）日本建築学会：鋼構造接合部の力学的性状に関する研究の 現状, 1993.10

6）呉 相贸, 秋山 宏 山田 哲: 柱-梁降伏型半剛接接合 部の挙動に関する研究, 日本建築学会関東支部研究報告集, pp.73 76, 1994.3

7）吳 相勲, 山田 哲, 秋山 宏: 無補強角形鋼管柱- $\mathrm{H}$ 形 梁接合部に関する研究, 日本建築学会学術講演梗概集（東 海), pp.1401 1402，1994.9

8）秋山 去, 高橋 誠: 鋼構造剛接骨組の耐震性に及ぼすバ ウシンガー効果の影響, 日本建築学会構造系論文集, 第 418 号, pp.49 57, 1990.12

9）桑村 仁, 邱 栄政, 秋山宏: 冷間ロール成形角形鋼管 の材質とその改善に関する研究, 日本建築学会構造系論文 報告集，第453号，pp.171 180，1993

10) Kazuhiko Kasai and Egor P. Popov: General Behavior of WF Steel Link Beams, Journal of Structural Engineering, Vol. 112, No. 2, pp.362 382, February, 1986

11）日本建築学会：鋼構造塑性設計指針， 1976

12) G. Davies, J.A. Packer: Predicting the strength of branch plate-RHS connections for punching shear-CAN. J, CIV. Engineering, Vol. 9, pp.458-467, 1982

（1995年 9 月 10 日原稿受理，1996年 1 月17日探用決定） 